\title{
IMPLIKASI PENGAMBILAN TODI DALAM KALANGAN MASYARAKAT INDIA LADANG DI TANAH MELAYU, 1900-1957
}

\author{
Parameswari Krishnan
}

\begin{abstract}
At present, studies on the history of Indians in colonial Malaya are described as onedimensional, with the discussion mainly focusing on their arrival as immigrant groups and their involvement in the estate sector. Other aspects of Indian history in colonial Malaya have not been given proper emphasis especially on matters considered taboo, such as those arising from toddy consumption. Toddy drink was newly acquired habit to many of the Indian labourers in Malaya. This needless temptation provided in estates at their very doors was the real reason for this. Many estates had many toddy shops and there were divisions on them. Toddy became a daily routine among the Indian labourers in spite of the fact that it was considered luxury and and excluded from their monthly budget. The introduction and supply of toddy in almost all estates led to consequences that affected the quality of life of the estate labour community. The effect went beyond the toddy drinkers themselves and included their families, the social system, and life in the estate overall. Realising this problem, this study focuses on the consumption of toddy and its effects on the Indian labour class in Malaya, 1900-1957. In the meantime, the three biggest implications focused in this paper are health, problems, poverty, and crime.
\end{abstract}

\section{Pengenalan}

Kaum India telah dibawa masuk secara beramai-ramai ke Tanah Melayu sekitar 1900 oleh penjajah British untuk menjayakan dasar ekonomi mereka, khususnya dalam sektor perladangan. Kecenderungan ini berlaku sekurang-kurangnya sejak tamat Perang Dunia Pertama, 1914- 
1918 dan jumlah orang India semakin bertambah sehinggalah negara ini mencapai kemerdekaan. Kehadiran masyarakat imigran ke Tanah Melayu mempunyai kisah sejarah yang cukup menarik. Kehadiran dan pertapakan orang Cina dikaitkan dengan candu dan kegiatan kongsi gelap. Kehadiran orang India pula dikaitkan dengan todi dan samsu. Orang India yang datang ke Tanah Melayu secara umumnya terbabit dalam sektor perburuhan terutamanya di ladang-ladang getah.

Todi dianggap menjadi punca utama keruntuhan imej buruh India di Tanah Melayu serta membantutkan perkembangan sosial kaum India di kawasan ladang. Golongan buruh ini hanya digunakan untuk menjayakan kepentingan pihak British serta majikan di ladang namun kebajikan mereka tidak diberi perhatian yang sewajarnya. Semua kemudahan yang disediakan kepada mereka hanya bertujuan untuk mengekalkan mereka di bawah sistem ikatan ladang dan bukan untuk membantu atau mengubah nasib hidup mereka. Oleh sebab buruh ini tidak dapat keluar dari ladang, maka hubungan dengan dunia luar terputus dan hal ini telah menghadkan pergaulan sosial mereka, bukan sahaja dengan golongan atasan malah antara sesama buruh sendiri.

Bagi kalangan buruh yang hidup dalam sistem ladang ini, semua keperluan yang disediakan oleh majikan sudah memadai dan mereka beranggapan kehidupan mereka di ladang sudah begitu lengkap. Dalam pada itu, kemudahan todi yang disediakan oleh majikan ladang telah mendorong pengambilan todi dalam kalangan buruh pada setiap hari. Buruh ladang menerima baik kehadiran dan kewujudan kedai todi disebabkan kedai ini merupakan satu-satunya tempat bagi mereka melepaskan tekanan. Pengenalan todi kemudiannya telah mengakibatkan ketagihan dalam kalangan buruh sehinggakan mereka tidak dapat bekerja tanpa mengambil todi terlebih dahulu. Tiga implikasi terbesar yang dikenal pasti melanda hampir semua buruh India ladang di Tanah Melayu akibat dari pengambilan todi ialah masalah kesihatan, kemiskinan dan masalah sosial. Maka, perbincangan seterusnya akan menjurus terhadap minuman todi disusuli dengan kesan-kesan pengambilan todi.

Topik ini sangat menarik untuk diperbincangkan kerana pelbagai risalah yang berhubung dengan todi dan masyarakat India dimuatkan untuk menggambarkan kesusahan yang dialami oleh buruh akibat pengambilan todi. Risalah-risalah tersebut sangat penting kerana memaparkan hidup buruh yang tidak dapat dipisahkan dengan todi. Risalah-risalah tersebut dicetak dan diterbitkan oleh kerajaan negara India dan dihantar kepada kerajaan British di Tanah Melayu. Risalahrisalah ini dikeluarkan atas tujuan melahirkan kesedaran dalam kalangan buruh India ladang bahawa tabiat meminum todi membawa pelbagai kesan buruk kepada masyarakat India, bukan sahaja dari sudut 
kesihatan, malah sosial dan ekonomi. Daripada sumber Arkib Negara Malaysia didapati risalah-risalah ini dicetak semula dan diedarkan kepada buruh-buruh India terutamanya masyarakat ladang oleh kerajaan negeri Kedah pada tahun 1941.

\section{Todi Tulen}

Todi merupakan jus bergula yang diambil dari bahagian putik bunga yang belum mekar di pokok kelapa atau diperolehi daripada pelbagai jenis pokok palma. ${ }^{1}$ Todi mengandungi sedikit alkohol, mempunyai Vitamin B2 dan tidak memudaratkan kesihatan jika diambil dalam kuantiti yang sederhana dan diminum dalam tempoh masa 12 jam daripada masa todi diambil dari pokok. ${ }^{2}$

Pada asasnya, sumber minuman yang dikumpul dari pokok kelapa disebut sebagai nira kerana belum melalui proses penapaian dan tidak mempunyai kandungan alkohol. Jika ada sekalipun, kandungannya hanya dalam kadar yang sangat kecil. ${ }^{3}$ Nira bermakna minuman yang baru sahaja diambil dari pokok dan tidak melalui sebarang proses penambahan bahan dan kesegaran ini kekal dalam tempoh 12 jam. Jika diambil dalam tempoh ini, todi bukan sahaja tidak menjejaskan kesihatan malah tidak memabukkan. ${ }^{4}$ Selepas nira melalui proses penapaian disebut sebagai todi. Proses ini berlaku dengan cepat ekoran wujudnya yis secara semula jadi. Proses penapaian sebenarnya berlaku sejurus selepas nira dikumpul iaitu selepas 1-2 jam dan ini berterusan sehingga kandungan alkohol meningkat sehingga 10 peratus. Selepas proses penapaian, todi yang dihasilkan harus diminum dalam tempoh 24 hingga 48 jam. Bagi 36 jam pertama, todi adalah minuman yang tidak merbahaya. Walau bagaimanapun, selepas tempoh 48 jam, todi tidak sesuai diminum. Selepas 60 jam, kandungan asid dalam todi adalah sangat tinggi dan jika diambil boleh menjejaskan kesihatan. ${ }^{5}$

\section{Todi Tidak Tulen}

Todi tidak tulen ialah todi yang telah mengalami campuran iaitu todi dicampur dengan pelbagai bahan yang boleh membawa ketagihan atau kemabukan tinggi seperti ganja, datura, alkohol, limau, samsu dan todi lama. Todi ini tidak asli lagi dan rasanya akan berubah mengikut bahan campuran. Datura (sejenis dadah dalam bentuk tumbuhan) dahulunya banyak digunakan di India dan mula menjadi ikutan orang India di Tanah Melayu. Datura merupakan sejenis tumbuhan yang dikatakan dapat menghasilkan keadaan mabuk dengan cepat. Biji datura akan ditumbuk dan hasilnya akan diikat dalam kain. Kemudian, hasil yang ditumbuk akan diperah ke dalam todi. ${ }^{6}$ 
Para peminum todi berpendapat campuran todi dengan datura dapat membawa mereka ke dunia yang lain dan menyeronokkan kerana campuran datura dalam todi dapat menghilangkan rasa todi lama. ${ }^{7}$ Campuran todi lama iaitu lebih dari 60 jam dengan todi baru juga menjadi punca utama dalam menjejaskan kesihatan buruh India. Campuran todi ini tidak dapat dibezakan rasanya dengan todi 36 jam. Lebih-lebih lagi, todi 60 jam dengan tambahan sedikit gula ataupun dengan sedikit alkohol, tidak dapat dibezakan rasa dengan todi 40 jam. Walau bagaimanapun, dalam kedua-dua cara ini, kandungan alkohol akan menurun dalam beberapa jam dan kandungan asidnya akan meningkat. Ini akan membahayakan kesihatan para peminum. ${ }^{8}$

\section{Permasalahan Istilah Todi}

Terdapat beberapa istilah yang harus diberi penjelasan. Hal ini penting kerana todi tulen tidak membawa kemudaratan atau implikasi teruk terhadap kesihatan buruh jika diambil dalam jumlah yang sederhana. Namun tidak dapat dinafikan bahawa, pengambilan todi tulen tanpa had masih boleh membawa kemudaratan kepada kesihatan buruh. Manakala, todi tidak tulen atau todi campuran pula menjejaskan kesihatan buruh dengan teruk sama ada diambil dalam kuantiti kecil atau besar. Menurut kajian ini, todi campuran inilah membawa masalah kesihatan terutama cirit-birit dan disentri terhadap buruh ladang dalam skala besar.

Antara istilah penting yang harus diberi perhatian ialah todi tulen atau todi segar dan todi tidak tulen atau todi tidak segar atau todi campuran. Istilah-istilah tersebut dirujuk dan diambil dari sumbersumber arkib. Todi tulen membawa maksud todi yang mengalami proses penapaian tetapi tidak dicampur dengan sebarang bahan campuran. Bagi masyarakat Melayu, todi tulen atau todi segar ini merujuk kepada nira. Manakala, todi campuran atau todi yang tidak tulen atau todi yang tidak segar ialah todi yang dicampur dengan pelbagai bahan yang boleh meningkatkan mabuk seperi gula, limau, alkohol, ganja, datura, todi lama dan sebagainya. Samsu ialah sejenis arak yang diperbuat daripada beras ditapai dan cecair. Semasa proses ini, yis, air, pisang, nanas, dan bahan-bahan lain ditambah. ${ }^{9}$ Samsu lebih berbahaya daripada todi di mana mengandungi alkohol sebanyak 37.96 peratus. ${ }^{10}$

\section{Implikasi Pengambilan Todi}

Harga todi sangat murah dan sumber todi yang terus wujud di kawasan ladang telah menjadi asas terpenting bagi buruh-buruh India mengambil todi secara meluas. Pengambilan todi terutama todi tidak 
tulen atau todi campuran seperti yang diterangkan dalam perbincangan di atas membawa kepada kewujudan permasalahan sosial atau penyakit sosial dalam masyarakat ladang. Pengambilan todi campuran ini telah membawa pelbagai implikasi ke atas buruh ladang sehingga mencemarkan masyarakat India ladang. Tiga implikasi yang akan menjadi fokus perbincangan adalah masalah kesihatan, kemiskinan dan jenayah. Ini kerana ketiga-tiga kesan tersebut menjadi masalah terbesar dalam kalangan buruh India ladang sepanjang zaman kolonial.

\section{Masalah Kesihatan}

Todi jika diambil dalam kadar yang berlebihan akan memabukkan. Jika tidak disediakan dengan bersih pula, ia boleh menyebabkan berbagai-bagai penyakit terutama cirit-birit dan keracunan hingga boleh membawa akibat yang sangat teruk kepada peminumnya dan sekiranya tidak dirawat dengan segera boleh membawa maut. Pada umumnya, penyediaan dan pembekalan todi kepada buruh-buruh ladang dilakukan tanpa mengambil kira aspek kebersihan.

\section{Gambar 1: Todi yang dikumpul di ladang kelapa tidak disediakan dalam keadaan bersih dan baldi-baldi yang digunakan untuk menuang todi didapati sangat kotor.}

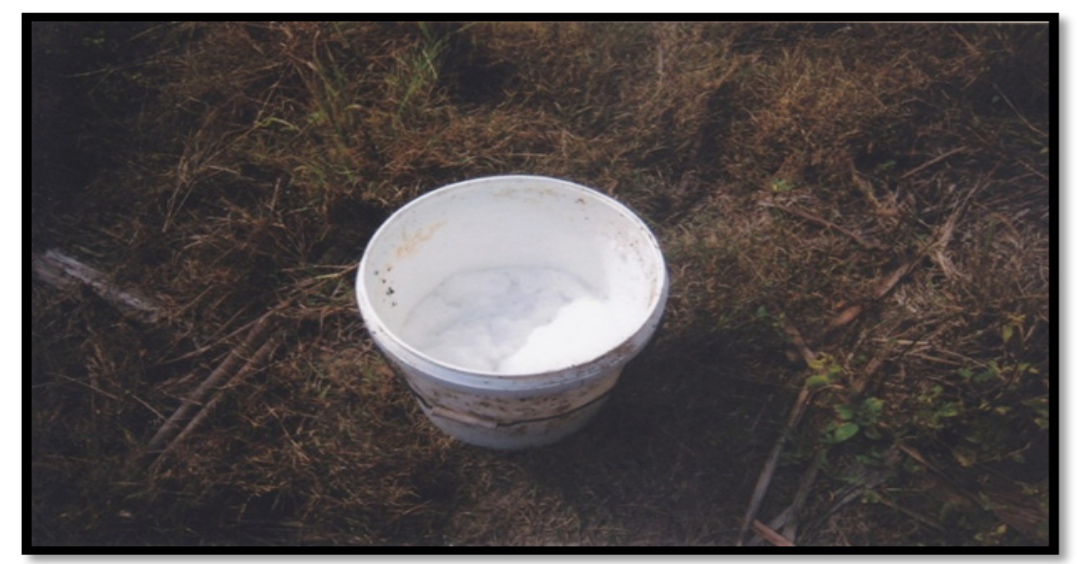

Sumber: Gambar diperolehi daripada kajian yang dilakukan di ladang todi Bagan Pasir, Hilir Perak, Perak pada 4 Mac 2013.

Disebabkan buruh-buruh India ladang tidak dibekalkan dengan kemudahan kesihatan yang baik sehingga tahun 1940-an, mereka telah menjadikan todi sebagai penawar, terutamanya untuk merawat penyakit malaria, sembelit, buasir, cirit-birit dan sebagainya. Kemudahan kesihatan yang langsung tidak memuaskan di kawasan ladang menyebabkan buruh-buruh menjadikan todi sebagai langkah 
awal pencegahan sesuatu penyakit. Walaupun tiada bukti jelas mengenai keberkesanan todi sebagai ubat, namun disebabkan masyarakat percaya bahawa ia mempunyai 'kuasa penyembuh', maka todi terus digunakan untuk merawat penyakit-penyakit tersebut. Keadaan ini pastinya turut dibantu dengan realiti bahawa di kebanyakan ladang langsung tidak mempunyai pusat rawatan bagi kemudahan pekerja dan jika ada sekalipun, kemudahannya tidak memuaskan. ${ }^{11}$ Bersandarkan kepada dua keadaan ini, maka tidak hairanlah sekiranya golongan buruh pada ketika itu menjadikan todi sebagai sumber yang penting untuk mengubati penyakit.

Walaupun buruh-buruh menganggap todi sebagai penyembuh kepada sesuatu penyakit, namun hakikatnya, todi itu sendiri memberi pelbagai implikasi yang buruk terhadap kesihatan. Todi yang dicampur dengan pelbagai bahan-bahan campuran misalnya mengakibatkan pelbagai masalah kesihatan dalam kalangan peminumnya. Pengambilan todi campuran ini sebenarnya semakin memburukkan keadaan. ${ }^{12}$ Keadaan ini berlaku apabila para pemilik kedai mencampurkan todi dengan bahan-bahan yang lain seperti limau, ganja, datura, alkohol, samsu, tepung, air dan sebagainya bagi meningkatkan ketagihan terhadap peminum todi. Keadaan ini dapat dilihat dari kenyataan Dr. M. Watson iaitu salah seorang ahli jawatankuasa yang bertanggungjawab menjalankan pemeriksaan kesihatan buruh-buruh di Selangor:

The question of the sale of intoxicants was one of very considerable importance to the heal th of estates. He did not want to talk about the subject of alcohol so much as on the quality of the liquor sold to the coolies. What seemed to have taken place was that - he supposed because the supply of good toddy was short - toddy shopkeepers had taken to adulterating it, and the result was disastrous in the extreme for the coolies. In some cases a native drug probably known to his hearers was put into the toddy. It was an intoxicant of sorts, and produced unconsciousness. He had quite a number of cases on one estate, which only stopped when the police raided the toddy shop and told the keeper that if such a condition of things continued his licence would be dealt with. As a result of that action the cases in that instance had ceased entirely. Other cases they got were those where an acute irritant poison had either developed in toddy or had been put in to it. ${ }^{13}$

Penjejasan kesihatan buruh akibat pengambilan todi dapat dilihat dalam gambar 2. Daripada gambar tersebut jelas bahawa pengambilan todi bukan sahaja menjejaskan rumah tangga seseorang buruh itu, malah memudaratkan kesihatan buruh itu dengan teruk. Buruh India di ladang sebenarnya ketagih dengan minuman todi kerana tidak dapat menikmati todi tulen. Mereka sentiasa menikmati todi campuran akibat 
dari tindakan pemilik kedai todi yang melakukan pelbagai campuran ke dalam todi demi mengaut untung besar.

Gambar 2: Gambar menunjukkan badan penjual todi yang semakin berisi hasil dari keuntungan yang diperolehi dari penjualan todi.

Manakala badan peminum todi menjadi semakin menyusut akibat terjejasnya kesihatan.

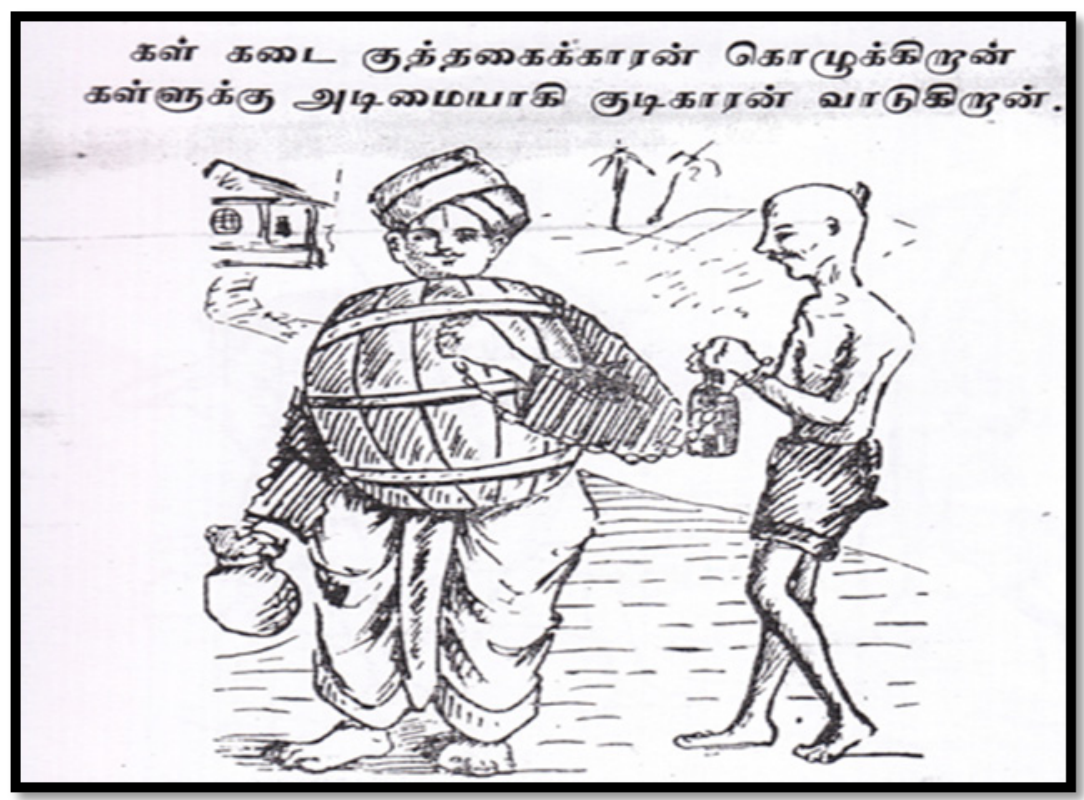

Sumber: Pamphlets On Toddy Drinking By Indian Labourers. Risalah Di Atas Perkara Minum Tuak Oleh Kuli-Kuli Hindu. (Versi Melayu-Jawi), dalam Fail Setiausaha Kerajaan Negeri Kedah, S.C.23-1360.

Amalan pengambilan todi campuran dan todi yang tidak tulen merupakan satu masalah yang tidak dapat dikawal dalam jangka pendek. Ini disebabkan hal tersebut telah berlaku di kawasan ladang sejak sekian lama. British yang menyedari hal ini mula mencari inisiatif bagi mengawalnya. Usaha telah dibuat pada tahun 1917, apabila sebuah jawatankuasa yang diketuai oleh Dr. Watson telah ditubuhkan bagi mengkaji aspek pengambilan todi dan kesannya terhadap kesihatan buruh di kawasan ladang. Dalam tahun yang sama, Dr. Watson juga telah menjalankan kajian dan pemeriksaan di beberapa hospital di negeri Selangor dan beliau kemudiannya telah menghasilkan "Proceedings and Reports of The Alleged Misuse and Abuse of Toddy Coast District Selangor". Dalam laporannya, beliau secara jelas menyatakan bahawa pengambilan todi campuran telah membawa kemudaratan terhadap kesihatan buruh 
di mana kebanyakannya mengalami cirit-birit dan disentri selepas mengambil minuman tersebut. ${ }^{14}$ Antara lain, Dr. Watson melaporkan:

Here is something definite, something serious, something in which we expect you, who are in charge of the public health, to take action'. All these cases were those of healthy coolies. Going round the different hospitals he saw a considerable number of cases of dysentery and diarrhea which he attributed to this toddy drinking. These cases were quite characteristic and apparently were the result of adulterated toddy or toddy kept until it was quite unfit to drink. In other cases where coolies had recovered they were peculiarly liable to a return of diarrhoea or dysentery. ${ }^{15}$

Dalam masa yang sama, penelitian Dr. Watson terhadap jumlah kes disentri dan diarrhoea di Hospital Batang Berjuntai, di Selangor menunjukkan wujudnya perbezaan di antara mereka yang mengambil todi dan mereka yang tidak mengambil todi.

Jadual 1: Jumlah kemasukan kes cirit-birit dan disentri ke Hospital Batang Berjuntai: (a) Peminum Todi (b) Bukan Peminum Todi

\begin{tabular}{|c|c|c|c|c|}
\hline \multirow{2}{*}{$\begin{array}{c}1916 \\
\text { Bulan }\end{array}$} & \multicolumn{2}{|c|}{ Jumlah Kemasukan } & \multicolumn{2}{|c|}{ Disentri dan Diarrhoea } \\
\hline & $\begin{array}{l}\text { Peminum } \\
\text { Todi }\end{array}$ & $\begin{array}{c}\text { Bukan Peminum } \\
\text { Todi }\end{array}$ & $\begin{array}{l}\text { Peminum } \\
\text { Todi }\end{array}$ & $\begin{array}{c}\text { Bukan } \\
\text { Peminum } \\
\text { Todi }\end{array}$ \\
\hline April & 13 & 12 & - & - \\
\hline Mei & 20 & 18 & - & - \\
\hline Jun & 37 & 18 & - & 1 \\
\hline July & 39 & 20 & 13 & - \\
\hline Ogos & 31 & 35 & 10 & 1 \\
\hline September & 28 & 10 & 5 & - \\
\hline Oktober & 34 & 12 & 4 & - \\
\hline Jumlah & 202 & $125^{*}$ & 32 & 2 \\
\hline
\end{tabular}

Sumber: Proceedings and Reports of the Commission, appointed to inquire into certain matters affecting the good government of the state of Selangor in relation to the alleged misuse and abuse of toddy in the coast district of Selangor - 1917, Kuala Lumpur: Federated Malay States Government Press, hlm. 278.

Jadual 1 dan graf 1 menunjukkan jumlah kemasukan peminum todi dan bukan peminum todi ke Hospital Batang Berjuntai pada tahun 1916. Daripada jumlah kemasukan 125 peminum bukan todi, 32 orang adalah kanak-kanak di bawah umur 14 tahun. Daripada jadual, didapati jumlah pesakit yang masuk ke hospital tersebut adalah seramai 327 orang dari bulan April hingga Oktober, 1916. Daripada angka ini, majoritinya adalah peminum todi iaitu seramai 202 orang. Dalam tempoh tersebut, seramai 32 orang yang dimasukkan ke hospital 


\section{Graf 1}

Jumlah Kemasukan Kes Diarrhoea dan Disentri ke Hospital Batang Berjuntai, Selangor Pada Tahun 1916.

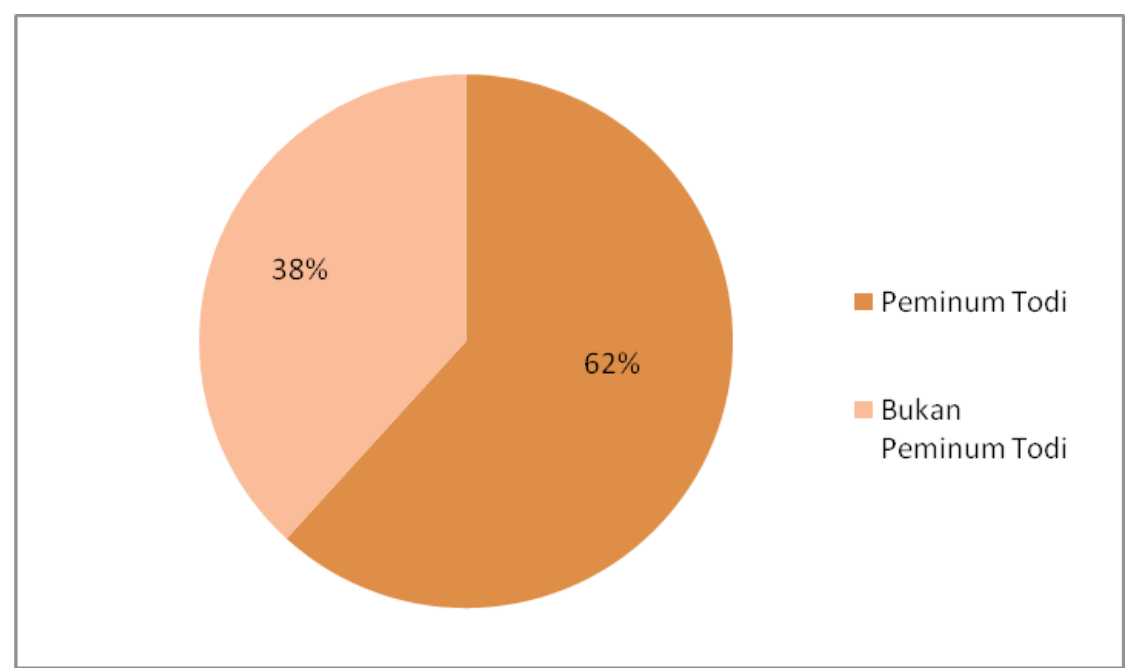

Sumber: Disesuaikan daripada, Proceedings and Reports of the Commission, appointed to inquire into certain matters affecting the good government of the state of Selangor in relation to the alleged misuse and abuse of toddy in the coast district of Selangor - 1917, Kuala Lumpur: Federated Malay States Government Press, hlm. 278.

tersebut adalah peminum todi yang menghidap penyakit disentri dan diarrhoea akibat daripada pengambilan todi sementara dua lagi pesakit terdiri daripada mereka yang tidak meminum todi. Antara tanda-tanda yang dihidapi oleh mangsa yang keracunan todi ialah pengsan, suhu badan tidak normal, badan menjadi sangat sejuk, nadi menjadi perlahan dan berpeluh. Malah, mangsa keracunan todi akan muntah, mengalami cirit-birit yang berlarutan dan sentiasa membuang air kecil. Tanda-tanda ini akan berlaku setelah beberapa jam mangsa mengambil todi dan mangsa boleh meninggal dunia dalam tempoh 36 jam. $^{16}$

Sementara di Johor pula, sebuah kedai todi berlesen yang dimiliki oleh Arumugam di Jalan Kluang, Batu Pahat didapati menjual todi campuran semata-mata untuk mengaut keuntungan yang lebih. Kualiti todi yang teruk ini telah menyebabkan buruh-buruh yang mengambilnya mengalami masalah kesihatan. Mereka mengalami pening melampau dan tidak dapat bangun awal pagi dan pergi kerja seperti biasa. ${ }^{17}$ 
Manakala di Kelantan, walaupun jumlah buruh India di negeri ini kecil, namun mereka tidak terlepas dari masalah kesihatan akibat daripada pengambilan todi. Seorang buruh yang dikenali sebagai Sithamparam dimasukkan ke hospital Tumpat, Kelantan pada tahun 1929 akibat pengambilan todi yang mengandungi asid yang sangat tinggi. Dalam surat yang ditulis kepada Penasihat British, Kelantan, Sithambaram menyatakan bahawa:

Kini pekerja-pekerja di Tumpat tidak dapat menikmati todi yang baik di Tumpat. Kami minum todi yang dicampur dengan air. Dahulu, ketika Nagamuthu menjual todi di Tumpat kami memiliki todi yang baik dan tidak mendapat sebarang penyakit. Kini, apabila menghampiri hospital untuk sebarang rawatan, doktor menasihati supaya jangan sentuh todi selepas ini. Gaji kami pula tidak membenarkan untuk memiliki minuman yang berkualiti tinggi. ${ }^{18}$

Penjualan todi campuran bukan sekadar menjejaskan kesihatan buruh, malah turut membawa kematian. ${ }^{19}$ Pengambilan todi tanpa had menyebabkan ramai memasuki hospital untuk menerima rawatan dan sebahagian dari mereka telah meninggal dunia. Jadual 2 menjelaskan keadaan tersebut.

Jadual 2 berikutnya secara jelas menunjukkan bahawa pengambilan todi tidak tulen telah menyebabkan kematian buruh dalam kadar yang tinggi di daerah Langat, Selangor. Hanya dalam lima bulan sahaja, seramai 15 buruh ladang memasuki hospital Langat dan sebahagian besar meninggal dunia. Salah satu kesan yang terpaksa diterima oleh peminum todi campuran adalah sakit perut dan cirit-birit yang berterusan. Ini kerap kali berlaku selepas mereka menikmati todi. Mereka juga mengalami simpton-simpton seperti muntah, pening dan tidak sedarkan diri. ${ }^{20}$ Diagnosis yang dilakukan di hospital mendapati bahawa keracunan yang dialami oleh pesakit-pesakit ini adalah kesan daripada pengambilan todi campuran dan tidak tulen yang dijual di kedai-kedai todi. Situasi ini menyebabkan mereka terpaksa dirawat di hospital dan berehat di rumah sehingga sembuh. Buruh-buruh ini juga tidak dapat bekerja dan ini sekaligus menjejaskan pendapatan mereka. ${ }^{21}$

Di sini, jelas memperlihatkan bahawa todi pada asalnya merupakan minuman yang tidak merbahaya hanya apabila diambil dalam kadar yang sepatutnya. Pengambilan todi dalam jumlah yang banyak akan menjejaskan kesihatan dan dalam beberapa keadaan, boleh membawa kepada kematian.

\section{Masalah Kemiskinan}

Pengambilan todi bukan sekadar menjejaskan kesihatan buruh, malah turut mengakibatkan golongan buruh kesempitan duit bagi 
Jadual 2: Kes yang masuk dan meninggal dunia di Langat Group Hospital akibat dari pengambilan todi campuran dalam Januari-Mei 1916

\begin{tabular}{|c|c|c|c|c|}
\hline Bil & Nama mangsa & Masuk & Keluar & Meninggal dunia \\
\hline 1 & Ponniah & $4-1-16$ & & $5-1-16$ \\
\hline 2 & Muthu & $17-1-16$ & & $18-1-16$ \\
\hline 3 & Sellagee & $21-1-16$ & & $29-1-16$ \\
\hline 4 & Sannasi & $7-2-16$ & & $7-2-16$ \\
\hline 5 & Pavady & $7-2-16$ & & $7-2-16$ \\
\hline 6 & Narayanan & $18-3-16$ & & $19-3-16$ \\
\hline 7 & Subrayan & $20-3-16$ & $25-3-16$ & \\
\hline 8 & Kathay & $20-3-16$ & $25-3-16$ & \\
\hline 9 & Govinday & & & $26-3-16$ \\
\hline 10 & Annamally & $26-3-16$ & & \\
\hline 11 & Kali & $30-3-16$ & $7-4-16$ & \\
\hline 12 & Munasamy & $31-3-16$ & $7-4-16$ & \\
\hline 13 & Ramanam & $31-3-16$ & $7-4-16$ & \\
\hline 14 & Ramasamy & $10-5-16$ & & $27-5-16$ \\
\hline 15 & Annandrum & $26-5-16$ & $27-5-16$ & \\
\hline
\end{tabular}

Sumber: Disesuaikan daripada, Proceedings and Reports of the Commision to the alleged misuse and abuse of toddy in the coast district of Selangor- 1917.

menyara keluarga sebahagian besar daripada sumber pendapatan mereka dihabiskan di kedai todi. Buruh merupakan golongan yang berpendapatan rendah yang bergantung sepenuhnya kepada hari mereka bekerja di ladang dan sekiranya mereka tidak dapat bekerja, maka mereka tidak akan dibayar gaji untuk hari tersebut. Walaupun buruh-buruh ini menerima gaji harian, namun itu tidak menghalang mereka untuk membelanjakan sebahagian besar pendapatan mereka di kedai-kedai todi pada setiap hari. Golongan buruh ini mula menjadi pengunjung tetap kedai todi dan membelanjakan wang tanpa had. Kajian secara jelas menunjukkan bahawa hampir 50-75 peratus dari sumber pendapatan buruh digunakan di kedai todi. ${ }^{22}$ Penggunaan jumlah pendapatan besar terhadap minuman todi ini menyebabkan kedudukan ekonomi mereka tidak stabil dan keadaan ini secara langsung menjejaskan kualiti kehidupan mereka dan mereka kekal miskin.

Kemiskinan dalam kalangan buruh merupakan isu yang berlarutan sepanjang zaman kolonial. Hal ini disebabkan kebanyakan buruh membuat pinjaman daripada majikan ladang atau kedai todi. Kemudian menyebabkan mereka terikat kepada majikan seumur hidup. Ini disebabkan bagi pembayaran balik hutang mereka, buruh-buruh ini terpaksa bekerja di bawah pengurusan atau tuan yang sama. Hal 
ini sama seperti yang telah berlaku kepada orang Cina yang menjadi ketagih terhadap candu. Mereka terikat kepada tuannya sehinggalah semua hutang diselesaikan sepenuhnya. ${ }^{23}$

Berdasarkan peraturan yang ditetapkan oleh kerajaan British, pemilik kedai todi tidak dibenarkan menjual todi secara hutang. Ini adalah untuk mengelakkan pelanggan yang sebahagian besarnya terdiri daripada buruh berpendapatan rendah daripada menanggung beban hutang yang tinggi. Walau bagaimanapun, kebanyakan pemilik kedai todi tidak mempedulikan peraturan ini dan tetap menjual todi secara kredit. Keadaan ini menyebabkan kehidupan buruh tidak berubah sebaliknya menjadi 'statik' di mana mereka tidak dapat melepaskan diri dari lingkaran kesusahan dan kemiskinan meskipun mempunyai pekerjaan dan dibayar gaji secara tetap. Lebih penting lagi, keadaan ini akan terus berlaku kepada generasi berikutnya apabila segala hutang yang dilakukan oleh ibu atau bapa sama ada dengan majikan atau pemilik kedai todi tidak dibayar. Mereka akan menjadi pembayar hutang yang ditinggalkan oleh bapanya ataupun ahli keluarganya di kedai todi atau kepada majikan ladang.

Biasanya, peniaga akan menyediakan buku kecil atau lebih dikenali sebagai buku tiga lima (555) bagi setiap peminum todi dengan menulis hutang yang diberikan kepadanya dan akan mengumpul semula hutang pada hari gaji. Fenomena buku tiga lima merupakan fenomena sosial yang sangat penting dan mempunyai kaitan langsung dengan persoalan hutang. Malah telah menjadi kebiasaan dalam konteks perkembangan sejarah sosial di negara ini hingga kini yang mengaitkan buku tiga lima dengan hutang. Biasanya, peniaga hanya akan membenarkan penggunaan buku tiga lima untuk pelanggan yang dikenali sahaja. Selain itu, bukan semua pelanggan yang dibenarkan berhutang di mana pelanggan tetap sahaja yang dibenarkan mempunyai akaun mereka di kedai tersebut. Dalam keadaan ini, kerap kali juga pelanggan, termasuklah di kedai todi tidak membuat pembayaran sekaligus untuk menyelesaikan hutang yang sedia ada, sebaliknya pembayaran dilakukan sedikit demi sedikit.

Secara umumnya, pengambilan todi secara berhutang telah menyumbang kepada pertambahan dalam bilangan peminum todi di sesebuah kawasan. Sebagai contoh di Perak, pengambilan todi secara berhutang telah meningkatkan bilangan peminum di negeri tersebut. ${ }^{24}$ Manakala di beberapa ladang di Kelantan, amalan memberi hutang diteruskan sehingga menyebabkan ramai buruh menghadapi kesempitan wang. Sementara itu, di beberapa buah ladang, todi dijual secara kredit dan potongan dibuat dalam Advances check roll buruh. 
Gambar 3: Gambar menunjukkan seorang buruh yang menggadai barang emas anaknya demi menikmati todi.

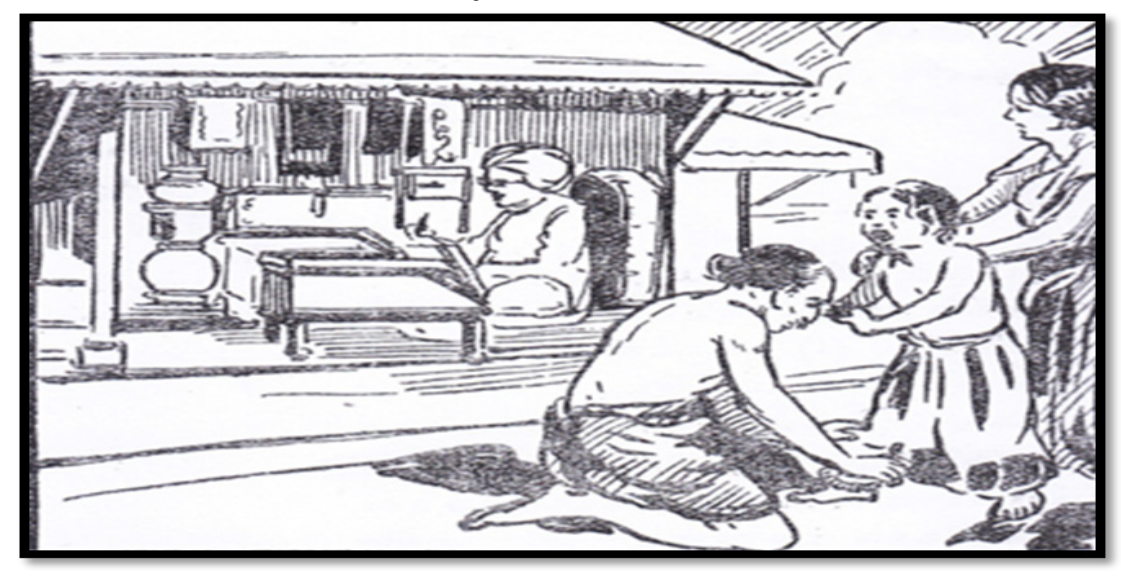

Sumber: Pamphlets On Toddy Drinking By Indian Labourers. Risalah Di Atas Perkara Minum Tuak Oleh Kuli-Kuli Hindu. (Versi Melayu-Jawi), dalam Fail Setiausaha Kerajaan Negeri Kedah, S.C.23-1360.

Pemberian hutang kepada peminum turut membabitkan negeri Kedah. Kedai todi ladang Sungai Ular, Kulim, Kedah misalnya didapati menjual todi kepada buruh-buruh di ladang secara kredit. Di enam buah kedai todi yang terdapat di antara Kulim dan Batu 9, dianggarkan kirakira 50 hingga 60 botol todi dibekalkan setiap hari di kawasan tersebut bagi menampung permintaan daripada 500 orang buruh. ${ }^{25}$ Adtchuthan yang merupakan penjual todi di ladang tersebut didapati menjual todi secara kredit tanpa sebarang had. Akibatnya, hutang buruh semakin bertambah. ${ }^{26}$

Penggunaan jumlah pendapatan yang besar terhadap minuman todi menyebabkan kedudukan ekonomi mereka tidak stabil dan keadaan ini secara langsung menjejaskan kualiti kehidupan mereka. Situasi ini dijelaskan secara terperinci dalam kenyataan berikut:

That was a perfectly sound point in normal times when the labourer earned enough money to ensure first of all that he and his family were well nourished and clothed. And what happens to his wife and children if he is encouraged to spend a considerable proportion of his income on Vitamin $B$ for himself? ${ }^{27}$

Buruh-buruh yang mementingkan todi ini sanggup membiarkan keluarga mereka tanpa keperluan asas yang cukup asalkan keperluan mereka terhadap todi dapat dipenuhi. Keadaan hidup buruh ini sewaktu di Tanah Melayu agak berbeza jika dibandingkan dengan di India kerana 
dalam banyak keadaan, keperluan asas mereka tidak dapat diperolehi dan kehidupan juga menjadi semakin sukar. Keadaan ini berlaku semata-mata kerana tindakan mereka sendiri yang menggunakan sebahagian besar pendapatan untuk membeli todi. ${ }^{28}$

Tekanan-tekanan ini menyebabkan ramai buruh mula menggunakan pendapatan mereka untuk minum todi. Menurut laporan Jabatan Buruh, "A high percentage of a labourers wages is spent on toddy and so diverted from the purchase of necessities. This waste of income prevents him from economic and general condition. ${ }^{29}$ Peminum todi menghabiskan wang yang dikumpul hasil daripada kerja di ladang setiap hari dan hal ini menyebabkan isteri dan anak-anak mengalami kesempitan hidup tanpa pakaian, makanan dan kelengkapan yang mencukupi. ${ }^{30}$ Ketagihan buruh terhadap todi menyebabkan, "Indulgence in toddy tends to the demoralization of the labourer and his family and to the complete and eternal damnation of the addict." 31

Gambar 4: Gambar menunjukkan seorang buruh miskin yang 'dibunuh' oleh minuman todi sedikit demi sedikit dan isteri dan anak-anak mengalami kesempitan hidup.

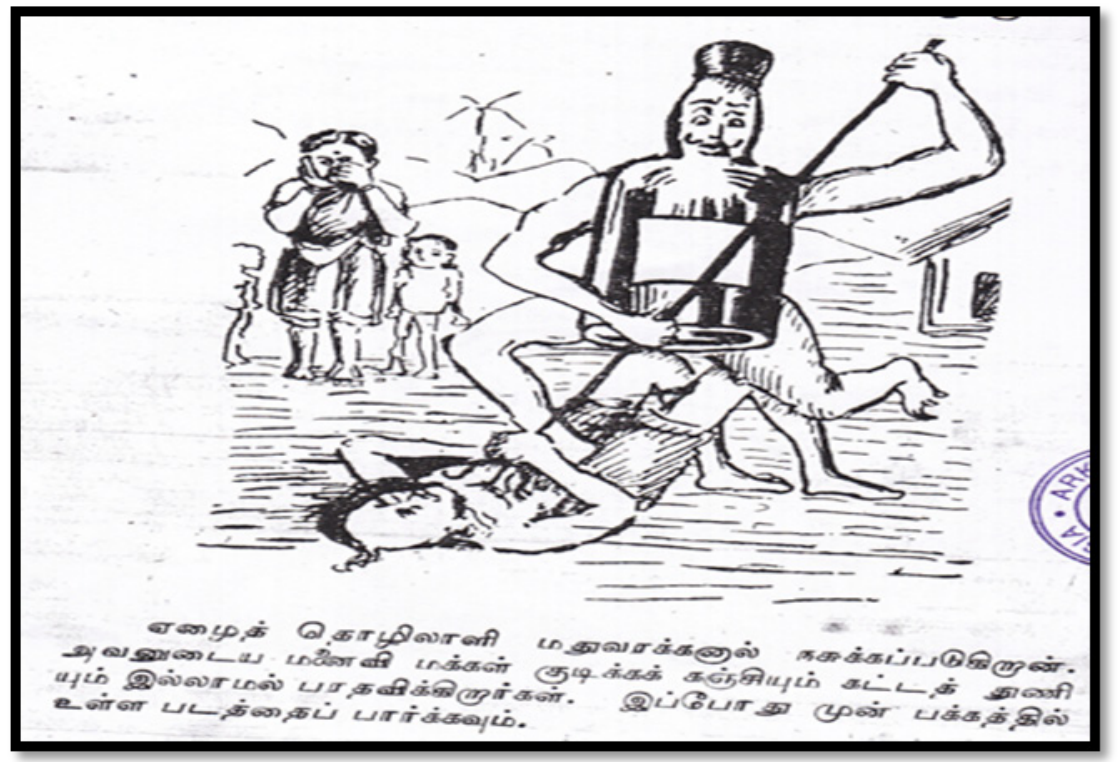

Sumber: Pamphlets On Toddy Drinking By Indian Labourers. Risalah Di Atas Perkara Minum Tuak Oleh Kuli-Kuli Hindu. (Versi Melayu-Jawi), dalam Fail Setiausaha Kerajaan Negeri Kedah, S.C.23-1360.

\section{Masalah Sosial}

Implikasi ketiga akibat daripada pengambilan todi secara tidak terkawal ialah pembabitan buruh dalam tindakan yang kurang bermoral seperti 
bergaduh, memukul isteri dan anak-anak, mencuri, menceroboh rumah, mencederakan orang lain, selalu ponteng kerja dan juga berani terlibat dalam pembunuhan. ${ }^{32}$ Kelakuan seseorang yang mabuk disifatkan sebagai "Actually the drunkard is compared to the animal or monkey's actions. "33 Gambar berikut menunjukkan tindakan peminum todi selepas menikmati todi.

Gambar 5: Gambar menunjukkan hidup buruh yang gembira dengan keluarga sebelum pengambilan todi dan buruh yang memukul isteri selepas terjebak dalam pengambilan todi.

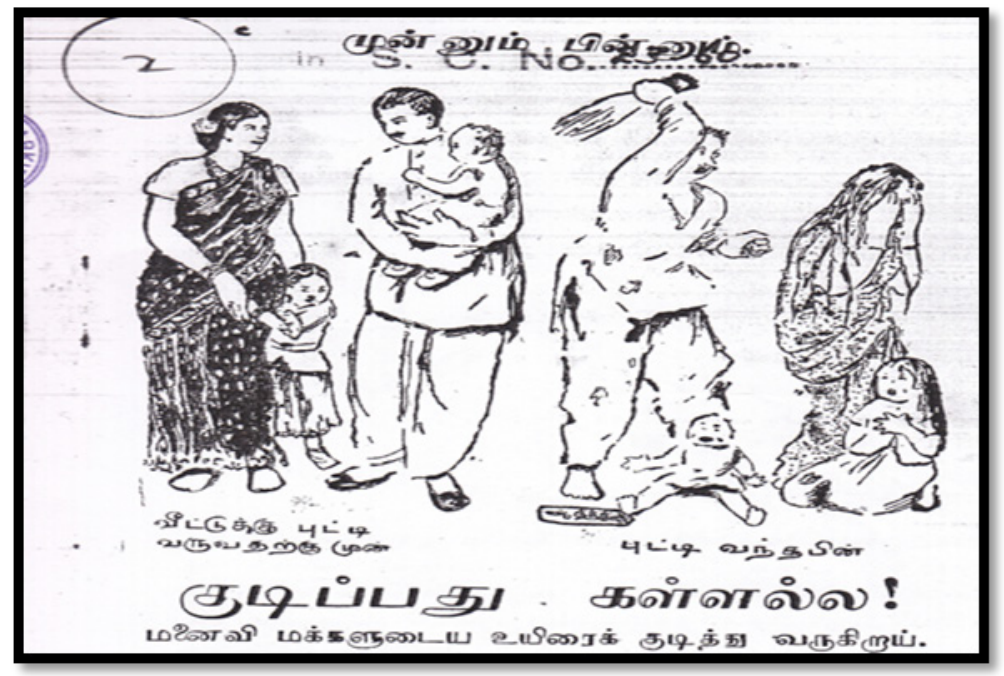

Sumber: Pamphlets On Toddy Drinking By Indian Labourers. Risalah Di Atas Perkara Minum Tuak Oleh Kuli-Kuli Hindu. (Versi Melayu-Jawi), dalam Fail Setiausaha Kerajaan Negeri Kedah, S.C.23-1360.

Dalam melihat kes-kes jenayah terutama pergaduhan dan pertikaian yang berpunca dari pengambilan todi Selangor mewakili tempat terbesar. Beberapa pengurus di Kapar iaitu Kinlock dari Ladang Jeram, Goodman dari Ladang Bukit Kraoing dan C. R. Hamerton dari Ladang Haston telah meminta kerajaan agar lesen kedai todi di Batu 4 tidak diluluskan bagi tahun seterusnya. Hal ini disebabkan oleh orang India di kedai todi tersebut yang sentiasa berada dalam keadaan mabuk, bergaduh dan menimbulkan pelbagai masalah. ${ }^{34}$ Peladang-peladang di Jalan Kapar pula meminta Pegawai Daerah, Klang untuk menutup kedai todi di Batu 6, Jalan Kapar dalam tahun 1916. Hal ini disebabkan oleh peminum-peminum todi di kedai itu sentiasa menimbulkan pelbagai masalah. ${ }^{35}$ Pergaduhan dalam kalangan buruh juga dapat dilihat di kawasan ladang Sabak Bernam, Kuala Selangor pada tahun 1914. Di kawasan tersebut, segelintir buruh Tamil yang meminum todi 
didapati telah bergaduh di kedai todi. Hal ini menyebabkan kerajaan membatalkan lesen kedai todi tersebut. ${ }^{36}$

Selain negeri Selangor, negeri Kedah juga merekodkan pergaduhan antara peminum todi yang mengambil todi secara berlebihan. Dianggarkan terdapat seramai 101 buruh lelaki Tamil dan 83 orang buruh lelaki Telugu di Ladang Sungkap, Kedah. Pada tahun 1925, penjualan todi dan samsu secara haram kepada penduduk di kawasan tersebut telah membawa kepada masalah pergaduhan di antara kedua belah pihak. Selain itu, di Ladang Kim Seng, berlaku pergaduhan dalam kalangan buruh-buruh yang berada dalam keadaan mabuk selepas pulang dari kedai todi Batu 25 1/2, Kuala Ketil, Kedah. ${ }^{37}$

Pengambilan todi secara meluas dalam kalangan buruh bukan sahaja membawa pergaduhan dan pertelingkahan, malah turut membawa kecederaan parah. Antaranya, pada malam 2 Julai 1929, sejumlah besar buruh di Ladang Serendah, Selangor menikmati todi dalam kuantiti yang banyak dan tidak dapat pulang ke rumah masing-masing kerana berada dalam mabuk. Seorang buruh bernama Gengan menimbulkan kekacauaan dalam kalangan buruh tersebut dan pergaduhan itu berakhir dengan Gengan mengalami kecederaan apabila pergelangan tangannya patah. Dalam penyiasatan yang dilakukan oleh Pegawai Daerah, Ulu Selangor, didapati bahawa kes mabuk meningkat kerana buruh India minum todi yang dicampur dengan stout. ${ }^{38}$ Manakala pada 18 September 1924, Santhanam dari Ladang Kapar, Klang, Selangor dan Ramasamy dari Ladang Sungai Bakok Raba, Selangor cuba mencederakan pemilik kedai todi yang enggan menjual todi secara kredit. ${ }^{39}$

Selain menyebabkan kecederaan parah, pengambilan todi secara keterlaluan menyebabkan buruh India membabitkan diri ke dalam jenayah yang lebih berat seperti pembunuhan. Pada 7 Jun 1924, seorang India bernama Ramasamy telah melakukan pembunuhan semasa berada dalam keadaan mabuk. Perkara yang sama dilakukan oleh Anandan, seorang buruh pada 8 Ogos 1924. Kes lain yang dilaporkan di Selangor, membabitkan Raman, seorang buruh di Ladang Tongkah, Selangor yang telah menikam seorang lelaki India yang telah menyerangnya pada 26 Mac 1924 ketika berada dalam keadaan mabuk. ${ }^{40}$

Walaupun kedai todi merupakan tempat yang menjadi pusat orang India berkumpul untuk minum dan menyelesaikan masalah peribadi mereka, kedai todi lebih tepat dikatakan sebagai tempat permulaan masalah sosial dalam kalangan buruh India. Sebagai contoh, berlaku pergaduhan di hadapan kedai todi ladang berhampiran Sentul yang telah membawa kepada pembunuhan. Dua orang India iaitu Ramachandran dan Vythilingam telah ditahan kerana membunuh seorang Bengali bernama Tehru pada 9 Oktober 1926. Menurut pengawal kedai todi 
Gambar 6: Gambar menunjukkan peminum todi yang terlibat dalam pertengkaran dan pergaduhan selepas menikmati todi.

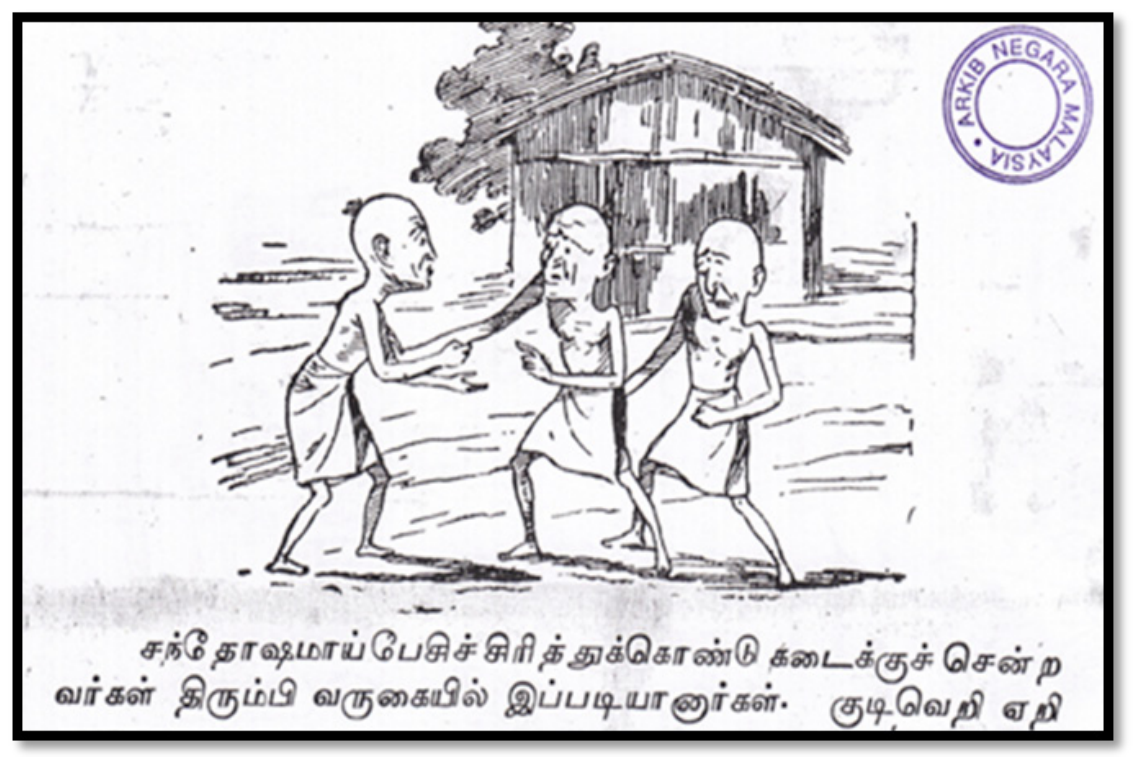

Sumber: Pamphlets On Toddy Drinking By Indian Labourers. Risalah Di Atas Perkara Minum Tuak Oleh Kuli-Kuli Hindu. (Versi Melayu-Jawi), dalam Fail Setiausaha Kerajaan Negeri Kedah, S.C.23-1360.

tersebut iaitu Hazel Deen, pergaduhan tercetus pada pukul 6.30 petang apabila ramai orang India dan Bengali berkumpul di hadapan kedai todi dengan bersenjatakan kayu. ${ }^{41}$ Selain itu, pada 4 Disember 1938, berlaku satu pertempuran dalam kalangan buruh di Ladang Sungai Manis, Klang, Selangor ketika mereka berada dalam keadaan mabuk. Dalam pertempuran ini, Periasamy, seorang buruh India telah dipukul oleh Angamuthu dengan sebatang kayu di bahagian kepala. Seterusnya, Periasamy telah dimasukkan ke hospital dan kemudian meninggal dunia selepas seminggu dirawat. ${ }^{42}$

Pembabitan buruh dalam aktiviti jenayah turut berlaku di Johor. Pada 18 April 1939, seorang buruh bernama Vellaiyan telah meninggal dunia dalam satu pertempuran yang berlaku di Ladang Gunung Pulai, Pontian, Johor. Mangsa dan pembunuh yang dikenali sebagai Karuppiah berada dalam keadaan mabuk ketika pertempuran itu berlangsung. ${ }^{43}$

Hampir kesemua masalah sosial dalam kalangan buruh India ladang ini berpunca daripada pengambilan todi campuran mahupun todi tidak tulen dalam kadar yang berlebihan. Pengambilan ini adalah 
akibat daripada sokongan pemilik kedai todi yang mencampurkan pelbagai bendasing ke dalam todi. Situasi ini telahpun dilaporkan oleh Pejabat Setiausaha Kerajaan Negeri Kedah seperti berikut:

Toddy as it is served to labourers is too much fermented and more than 24 hours old increasing the percentage of acid. Some of the distributors keep it for a number of days and mix the residue with fresh toddy to give it a better kick; sometime it is mixed with stramonium leaves, poppy seeds and boiled rice water. I have seen some labourers going completely under the influence of the drink on one or two pints becoming boisterous rowdy and provocative. ${ }^{44}$

Gambar 7: Gambar menunjukkan peminum todi yang terbabit dalam jenayah pembunuhan selepas menikmati todi.

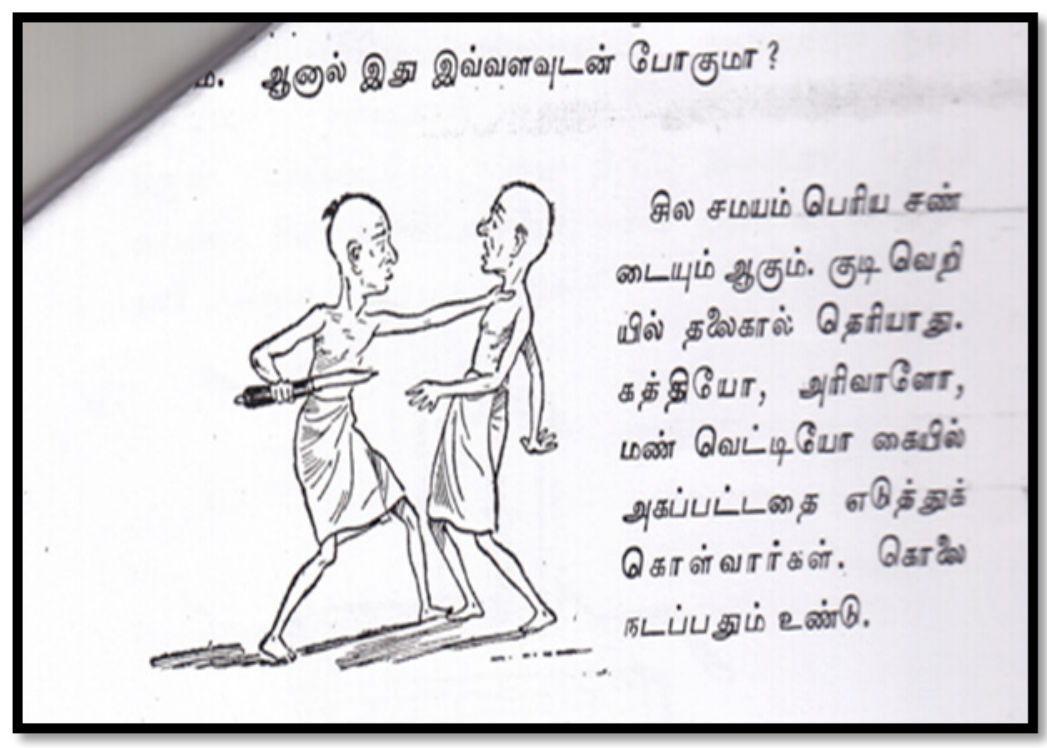

Sumber: Pamphlets On Toddy Drinking By Indian Labourers. Risalah Di Atas Perkara Minum Tuak Oleh Kuli-Kuli Hindu. (Versi Melayu-Jawi), dalam Fail Setiausaha Kerajaan Negeri Kedah, S.C.23-1360.

Penglibatan buruh-buruh ladang dalam pelbagai masalah sosial akibat dari pengambilan todi telah menyebabkan Jabatan Buruh mula menerima banyak aduan dari ladang-ladang. Jadual 3 menunjukkan aduan berkenaan pergaduhan dalam kalangan buruh India yang diterima oleh Jabatan Buruh dari seluruh Tanah Melayu.

Berdasarkan jadual 3 dan graf 2 hampir di setiap negeri berlaku pergaduhan dalam kalangan buruh India di ladang. Pergaduhan di Negeri-negeri Melayu Bersekutu pada tahun 1929 sangat tinggi iaitu sebanyak 285 kes. Manakala di Negeri-negeri Selat dan di Negeri-negeri 
Melayu Tidak Bersekutu, masing-masing mencatatkan sebanyak 100 dan 85 kes pergaduhan dalam kalangan buruh. Dalam tempoh 5 tahun, pergaduhan paling tinggi dicatatkan pada tahun 1929 di ketiga-tiga koloni disebabkan pada tahun tersebut, jumlah kedai todi adalah yang paling tertinggi. Di Negeri-negeri Melayu Bersekutu, bilangan kedai todi pada tahun 1928 adalah sebanyak 348 dan meningkat kepada 355 pada tahun 1929. Manakala di Negeri-negeri Selat, bilangan kedai todi pada tahun 1928 ialah sebanyak 178 dan meningkat kepada 180 pada tahun 1929. Sementara itu, di Negeri-negeri Melayu Tidak Bersekutu, misalnya di Kedah, jumlah kedai todi pada tahun 1928 adalah sebanyak 111 dan jumlah ini meningkat kepada 146 pada tahun $1929 .{ }^{45}$

Jadual 3: Aduan mengenai pergaduhan dalam kalangan buruh India ladang yang diterima oleh Jabatan Buruh di Tanah Melayu dari tahun 1928 sehingga 1932

\begin{tabular}{|c|c|c|c|c|}
\hline \multirow[t]{2}{*}{ Tahun } & \multirow{2}{*}{$\begin{array}{c}\text { Negeri-negeri } \\
\text { Melayu } \\
\text { Bersekutu }\end{array}$} & \multirow[t]{2}{*}{$\begin{array}{l}\text { Negeri-negeri } \\
\text { Selat }\end{array}$} & \multicolumn{2}{|c|}{$\begin{array}{l}\text { Negeri-negeri Melayu } \\
\text { Tidak Bersekutu }\end{array}$} \\
\hline & & & Kedah & Johor \\
\hline 1928 & 217 & 73 & 33 & 34 \\
\hline 1929 & 285 & 100 & 28 & 57 \\
\hline 1930 & 179 & 49 & 53 & 22 \\
\hline 1931 & 84 & 44 & 51 & 21 \\
\hline 1932 & 70 & 29 & 70 & 11 \\
\hline
\end{tabular}

Sumber: Annual Report of The Agent of The Government of India In British Malaya For The Year 1928-1932, Calcutta: Government of India, Central Publication Branch, 1929-1933.

Graf 2: Aduan mengenai pergaduhan dalam kalangan buruh India ladang yang diterima oleh Jabatan Buruh di Tanah Melayu dari tahun 1928 sehingga 1932

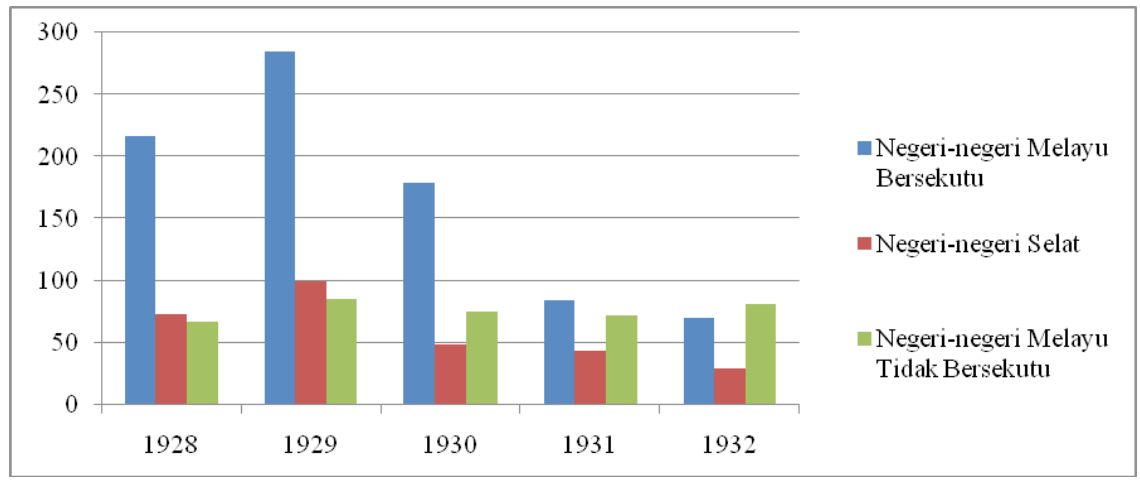

Sumber: Disesuaikan daripada, Sumber: Annual Report of The Agent of The Government of India In British Malaya For The Year 1928-1932, Calcutta: Government of India, Central Publication Branch, 1929-1933. 
Selepas meneliti perbincangan di atas, jelas bahawa penglibatan buruh India dalam masalah-masalah jenayah berpunca daripada kewujudan kedai todi yang terdapat hampir di setiap ladang. Pihak majikan ladang menyebut, "in fact, prostituted toddy to the starved immigrants to gain economic benefits for themselves." 46 Selain keuntungan, niat pihak ini adalah menjadikan buruh-buruh sebagai hamba kepada todi dan hidup berpecah belah. Bagi kerajaan British yang penting ialah memerintah buruh dengan mudah dan bukannya menjaga kepentingan kumpulan buruh.

Pengaruh todi yang begitu kuat dalam kalangan buruh menyebabkan ada di antara mereka yang sanggup bersusah payah berjalan berbatu-batu demi mendapatkan todi. Di Johor, buruh-buruh Tamil di ladang Tanjong Labu, Batu Pahat, Johor berjalan sejauh 3 ke 4 batu setiap hari ke Banang untuk mendapatkan todi walaupun dijual dengan harga yang sangat tinggi. ${ }^{47}$ Sementara itu, seramai 100 orang buruh dari ladang Kan Kar, Batu Pahat, Johor turut berjalan kaki sejauh tujuh batu ke Parit Sulung bagi memperolehi minuman todi selepas balik dari kerja. ${ }^{48}$ Tindakan buruh yang sanggup berjalan berbatu-batu semata-mata mahu mendapatkan todi telah memberi kesan kepada prestasi kerja mereka. Hal ini disebabkan ada dalam kalangan mereka yang tidak dapat melakukan pekerjaan dengan baik ekoran keletihan setelah pulang dari mendapatkan todi. Hal ini telah menyebabkan pengurus ladang kelapa dan getah di Batu Pahat memohon lesen yang segera daripada Jabatan Perlesenan Batu Pahat untuk mengelakkan seramai 75 orang buruh di ladang tersebut pergi ladang lain untuk mendapatkan minuman todi pada waktu bekerja. ${ }^{49}$

Penglibatan buruh India ladang dalam pengambilan todi dapat dilihat dalam perbincangan berikut. Jadual 4 dan graf 3 menunjukkan pengambilan todi oleh kalangan buruh India di Johor. ${ }^{50}$ Jumlah buruh yang terlibat dalam pengambilan todi ini sebenarnya membuktikan betapa kuatnya ikatan todi dengan buruh India ladang.

Jadual 4: Jumlah peratus peminum todi lelaki dan wanita di negeri Johor pada tahun 1946

\begin{tabular}{|c|c|c|c|}
\hline Kawasan & Jumlah Buruh & Jumlah Peratus Peminum Todi (\%) \\
\hline & & Lelaki & Wanita \\
\hline Kluang & 1,093 & $90 \%$ & $10 \%$ \\
\hline Rengam & 1,073 & $93 \%$ & $7 \%$ \\
\hline Paloh & 1,100 & $66 \%$ & $34 \%$ \\
\hline Labis & 1,432 & $89 \%$ & $11 \%$ \\
\hline Kahang & 258 & $76 \%$ & $24 \%$ \\
\hline Mersing & 118 & $85 \%$ & $15 \%$ \\
\hline
\end{tabular}

Sumber: Toddy Committee, dalam Fail Labour Department of Malaysia, 1945-1947, LDM 426/46. 
Graf 3: Jumlah peratus peminum todi lelaki dan wanita di negeri Johor pada tahun 1946

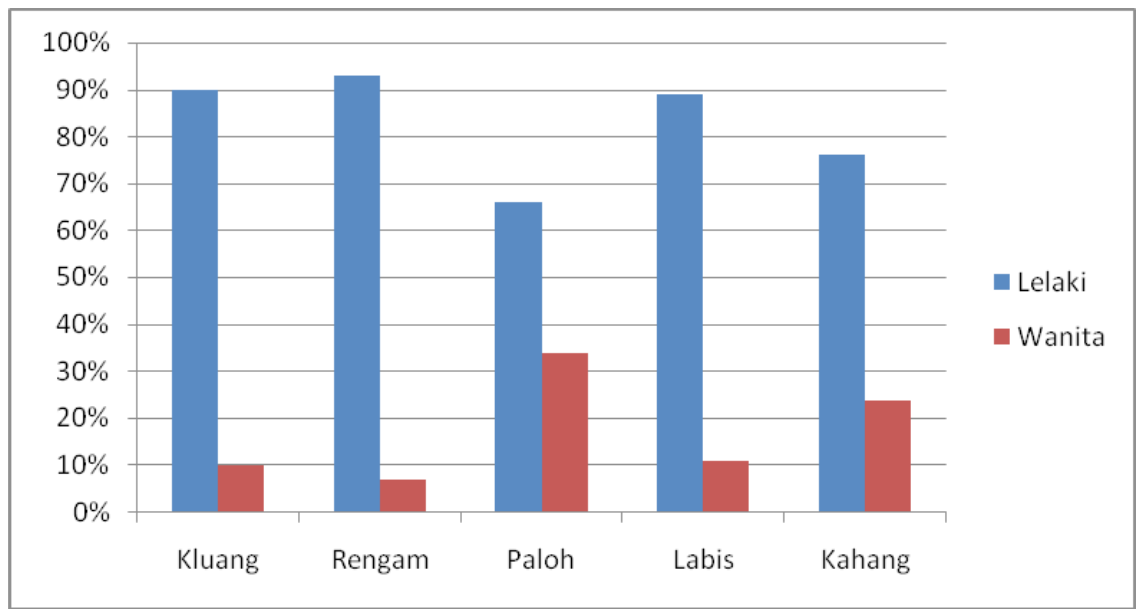

Sumber: Disesuaikan daripada, Toddy Committee, dalam Fail Labour Department of Malaysia, 1945-1947, LDM 426/46.

Jadual 4 dan graf 3 menunjukkan jumlah peratus lelaki dan wanita yang terlibat dalam pengambilan todi di enam buah daerah di negeri Johor iaitu Kluang, Rengam, Paloh, Labis, Kahang dan Mersing pada tahun 1946. Peratus peminum todi diambilkira daripada 10 buah ladang di Kluang, tujuh buah ladang di Rengam, 10 buah ladang di Paloh, daerah Utara di ladang Johor Labis, dua buah ladang di Kahang dan dua buah ladang di Mersing. Didapati buruh lelaki India adalah peminum todi tertinggi di setiap daerah tersebut. Ini disebabkan todi boleh diperolehi dengan mudah dan harga yang murah. ${ }^{51}$ Berdasarkan graf di atas, meskipun peminum todi yang terbesar adalah dalam kalangan lelaki, namun tidak dapat dinafikan bahawa, wanita juga terlibat dalam aktiviti pengambilan todi hampir di setiap ladang di negeri Johor. Hampir di setiap daerah tersebut, peminum lelaki mewakili 80 peratus ke atas misalnya di Kluang, Rengam, Mersing dan Labis. Sementara itu, golongan wanita masih tergolong dalam kumpulan peminum yang kecil. Namun begitu, di beberapa daerah seperti Paloh dan Kahang, peminum wanita adalah 34 peratus dan 24 peratus. Ini merupakan satu jumlah yang besar jika dibandingkan dengan daerah-daerah lain.

Jika dilihat secara keseluruhan, jelas bahawa, todi menjadi minuman penting dalam hidup buruh terutama buruh lelaki. Hal ini sudah pasti berhubung dengan pekerjaan, tekanan hidup yang mereka lalui, masalah keluarga dan sebagainya. Ini bererti pelbagai faktor mendorong mereka terlibat dalam pengambilan todi seperti 
yang dibincangkan dalam bab ini. Jadual dan graf di atas amat penting bagi memperolehi gambaran di negeri-negeri lain. Keadaan yang sama dapat diperhatikan dalam kalangan buruh hampir di seluruh Tanah Melayu ketika zaman kolonial. Penjelasan di atas menunjukkan bahawa, berbanding wanita, lelaki merupakan golongan majoriti yang terlibat dalam pengambilan todi. Selain peratus buruh yang mengambil todi, jumlah todi yang diminum oleh buruh-buruh juga perlu dilihat untuk mengetahui sejauhmana todi mempengaruhi hidup mereka.

\section{Kesimpulan}

Secara keseluruhan didapati bahawa, pengambilan todi dalam kalangan buruh India ladang di Tanah Melayu merupakan suatu perancangan British. Ini kerana British melihat 'todi' sebagai formula yang dapat menstabilkan masyarakat ladang dan pada masa yang sama penjajah sedar bahawa lebih mudah bagi memerintah buruh yang berada di bawah pengaruh alkohol. Pada perkiraan majikan ladang yang rataratanya orang Eropah, masa lapang buruh adalah satu keadaan berisiko dan boleh membawa masalah sosial yang besar. British sedar bahawa pengenalan 'todi' adalah satu-satunya kaedah yang terbaik untuk mengekalkan mereka di ladang-ladang. Bagi memudahkan usaha British mengawal buruh-buruh ini, maka todi mula disediakan dekat dengan buruh dan harga yang murah.

Daripada perbincangan makalah ini, dapat dikenalpasti bahawa implikasi yang sangat besar terhadap buruh India akibat daripada pengambilan todi tidak tulen ialah masalah kesihatan. Daripada perbincangan aspek ini, didapati ramai buruh India sentiasa dikejarkan ke hospital ladang selepas mengambil todi. Perkara yang paling memeranjatkan ialah ramai buruh meninggal dunia selepas mengambil todi. Kes-kes kematian akibat daripada pengambilan todi yang dilihat dalam makalah ini sudah memadai untuk kita menyimpulkan bahawa todi menjadi satu masalah utama dalam kalangan buruh India di Tanah Melayu pada zaman kolonial.

Selain masalah kesihatan, satu lagi masalah terbesar yang wujud dalam kalangan buruh ialah jenayah. Daripada kajian di atas, didapati ramai buruh terbabit dalam kegiatan jenayah ringan mahupun jenayah yang lebih besar ketika mabuk. Jenayah ringan yang sentiasa membabitkan buruh-buruh India di ladang ialah pergaduhan, pertengkaran, pertelingkahan, memukul isteri dan anak, mencederakan orang lain, menceroboh ladang, mencuri dan menganggu ketenteraman keluarga dan masyarakat sekitar. Manakala jenayah berat yang melibatkan mereka ialah pembunuhan. Ini bererti, masalah jenayah dalam kalangan orang India telah pun berakar sejak zaman British lagi. 
Kajian juga membuktikan bahawa, golongan buruh ini terus berada dalam cengkaman kemiskinan akibat dari pengambilan todi secara berhutang dan kesusahan mereka pula berlarutan.

\section{Nota}

$1 \quad$ CO 874/881, Surat daripada The Government Secretary, Jesselton. Lihat juga, CO 439/3, Federated Malay States, Selangor Administration Report For The Year 1922, Kuala Lumpur: The F.M.S. Government Printing Office, 1923, hlm. 5.

2 The Toddy Tapping Industry, dalam tajuk Estates Toddy Shop In The State of Malacca, dalam Fail Jabatan Buruh Melaka 1945-1954, JBM 41/45, hlm. 1-3. Rujuk juga, Memorandum On Toddy shops and Drunkenness by Indian Labourers, dalam tajuk Government Policy With Regard To Toddy, dalam Fail Setiausaha Kerajaan Negeri Selangor, Selangor Secretariat File 3780/1922, hlm. 4; Second Supplement To The Federated Malay States Government Gazette, Vol. XIV, 9 November 1922, hlm. 2050.

3 Peratus alkohol dalam todi tulen adalah 5.7 volume atau 4.9 weight. Lihat, CO 273/411, Surat daripada M. P. Lewis Harcourt, Colonial Office, 24 Jun 1914.

$4 \quad$ Ibid. Lihat juga, CO 439/3, Federated Malay States, Selangor Administration Report For The Year 1922, Kuala Lumpur: The F.M.S. Government Printing Office, 1923, hlm. 5; A. Paramasivam, 'Toddy Drinking in Malaysia', dalam Seminar on Health, Food and Nutrition, Penang, 15-20 September 1979, hlm. 3.

5 CO 273/411, Surat daripada M. P. Lewis Harcourt, Colonial Office, 24 Jun 1914. Lihat juga, Toddy Tapping Industry, dalam tajuk Estates Toddy Shop In The State of Malacca, dalam Fail Jabatan Buruh Melaka, 1945-1954, JBM 41/45, hlm. 3; Memorandum On Toddy shops and Drunkenness by Indian Labourers, dalam tajuk Government Policy Withy Regard To Toddy, dalam Fail Pejabat Setiausaha Kerajaan Negeri Selangor, Selangor Secretariat File 3780/1922, hlm. 4; Second Supplement To The Federated Malay States Government Gazette, Vol. XIV, 9 November 1922, hlm. 2057; A. Paramasivam, 'Toddy Drinking in Malaysia', hlm. 3.

$6 \quad$ Proceedings and Reports of the Commission, appointed to inquire into certain matters affecting the good government of the state of Selangor in relation to the alleged misuse and abuse of toddy in the coast district of Selangor - 1917, Kuala Lumpur: Federated Malay States Government Press, 1917, hlm. 71.

7 Ibid., hlm. 298.

$8 \quad$ Negeri Sembilan Secretariat File 2292/1922, Governments Policy with Regard to Toddy Forward Pamplet entitiled, From Commisioner, Trade and Customs to Resident Selangor, F. M. S, 22 September 192, hlm. 4.

9 J. R. Daniel, 'A Socio Economic Study Of The Indians In The Rubber and Oil Palm Estates in the State of Perak and Selangor', M.A. Thesis, History Department, University of Malaya, Kuala Lumpur, 1980, hlm 106-107.

10 Proceedings and Reports of the Commission to the alleged misuse and abuse of toddy in the coast district of Selangor-1917, hlm. 171. 
11 CO 273/398, Health of Labourers Perhentian Tinggi Estate (Including Hansa and Margot Estates) 1910, Kuala Lumpur: The F.M.S. Government Printing Office, 1911, hlm. 15.

12 CO 439/2, Federated Malay States, Selangor Administration Report For The Year 1918, Kuala Lumpur: The F.M.S. Government Printing Office, 1919, hlm. 8.

13 Ucapan Dr.Watson dalam Planter's Association of Malaya pada 29 April 1916. Lihat, Owing of Kapar toddy shop by a Chinaman and Death of coolies at Kapar Hospital from toddy poisoning, dalam Fail Setiausaha Kerajaan Negeri Selangor, Selangor Secretariat File 2504/1916.

14 CO273/410, Surat dari Government House, Singapore, April 1914.

15 Owing of Kapar toddy shop by a Chinaman and Death of coolies at Kapar Hospital from toddy poisoning, dalam Fail Setiausaha Kerajaan Negeri Selangor, Selangor Secretariat File 2504/1916.

Proceedings and Reports of the Commission to the alleged misuse and abuse of toddy in the coast district of Selangor-1917, hlm. 294. Surat daripada Malcolm Watson kepada The Under Secretary, Federated Malay States, Kuala Lumpur, 11 Julai 1916. Dalam tahun 1910, buruh-buruh di ladang Perhentian, Hansa dan Margot langsung tidak disediakan kemudahan kesihatan yang baik. Beratus-ratus buruh menderita akibat dari kekurangan rawatan di hospital dan beratus-ratus buruh lagi mati begitu sahaja tanpa menerima sebarang rawatan. Lihat, CO 273/398, Health of Labourers Perhentian Tinggi Estate (Including Hansa and Margot Estates) 1910, Kuala Lumpur: The F.M.S. Government Printing Office, 1911, hlm. 15-16. Sebelum mempunyai lesen di Batu Pahat, Arumugam mempunyai dua buah kedai todi di Singgaram dan Kluang, Johor dan akhirnya terpaksa ditutup akibat penjualan todi yang dicampur dengan pelbagai bahan yang memudaratkan kesihatan buruh. Kerajaan menarik lesennya apabila terdapat banyak aduan daripada orang awam di situ. Lihat, Complaints against the bad stuffs used by the Toddy Shop at Jalan Kluang in making toddy for sale to the public, dalam Fail Pejabat Tanah Batu Pahat, 19141931, AABP 51/25. Surat daripada P.W.D. Coolies kepada The Chairman, Licensing Board of Toddy Shops, Batu Pahat, 7 Jun 1925.

18 Complain that the toddy sold at Tumpat toddy shop is polluted by mixing with water etc. and thereby causes sickness among them, dalam Fail British Adviser's Office Kelantan, BAOK 1546/1929.

CO 273/411, Surat daripada M. P. Lewis Harcourt, Colonial Office, 24 Jun 1914.

20 Proceedings and Reports of the Commission to the alleged misuse and abuse of toddy in the coast district of Selangor- 1917, hlm. 296.

21 Methods of Collecting and Storing Toddy, dalam Fail Setiausaha Kerajaan Negeri Selangor, Selangor Secretariat File 3851/1917. Surat daripada Chairman of Licensing Board kepada Residen Selangor, Kuala Selangor, 22 September 1917. The Year 1934, Delhi: Manager of Publications, 1935, hlm. 14. CO 273/394, Opium. 
24 Proceedings and Reports of the Commission to the alleged misuse and abuse of toddy in the coast district of Selangor- 1917, hlm. 346-347. Surat daripada R. G. Watson, British Resident Perak kepada British Residency, Taiping, Perak, 12 September 1913.

25 Manager, Sungai Ular Estate complains against one Adtchuthan, a toddy shop keeper for selling adulterated toddy to his coolies - Manager Sungai Ular Rubber Estate mengadu di atas Adchuthan yang buka kedai tuak fasal ia jual tuak yang busuk kepada kuli-kulinya (Versi Melayu-Jawi), dalam Fail Setiausaha Kerajaan Negeri Kedah, Kedah Secretariat File 2873/1342. Surat ini daripada Manager Sungai Ular Estate kepada The Controller of Labour, Penang, 17 Jun 1924.

26 Ibid. Surat ini daripada Manager Sungai Ular Estate kepada Member of Licensing Board Committee, Bukit Mertajam Rubber Estate, Kulim, 27 Februari 1924.

27 Manager, Sungai Ular Estate complains against one Adtchuthan, a toddy shop keeper for selling adulterated toddy to his coolies - Manager Sungai Ular Rubber Estate mengadu di atas Adchuthan yang buka kedai tuak fasal ia jual tuak yang busuk kepada kuli-kulinya (Versi Melayu-Jawi), dalam Fail Setiausaha Kerajaan Negeri Kedah, Kedah Secretariat File $2873 / 1342$.

George Netto, Indians in Malaya: Historical Facts and Figures, Singapore: George Netto, 1961, hlm. 37. Annual Report of The Agent of The Government of India In British Malaya For The Year 1934, Delhi: Manager of Publications, 1935, hlm. 14. Pamphlets on Toddy drinking by Indian labourers. Risalah di atas perkara minum tuak oleh kuli-kuli Hindu (versi Melayu-Jawi), dalam Fail Pejabat Setiausaha Kerajaaan Negeri Kedah, S.C.23-1360, hlm. 4.

31 Indian Daily Mail, Singapore, 28 September 1946. Notes and Comments: Toddy Evil and The Malayan Government, dalam tajuk Toddy Committee, dalam Fail Labour Department of Malaysia, 1945-1947, LDM 426/46, hlm. 9.

32 CO 273/563, Surat daripada Governer's Deputy kepada Colonial Office, 29 April 1930, hlm. 1. Lihat juga, 'Growing Menace of Alcoholism In Malaya', Indian Daily Mail, 2 Jun 1947, hlm. 2.

33 Malacca Tamil Labourers Association. a) Education b) Toddy Shops c) Meetings, dalam Fail Resident's Commissioner's Office Malacca, H.C.MALACCA 260/1946.

34 Right to Sell Toddy in the Klang, dalam Fail Setiausaha Kerajaan Negeri Selangor, Selangor Secretariat File 3531/1911. Surat daripada District Officer kepada Resident Selangor, 26 Oktober 1911.

35 Closing of the toddy shop at the $6^{\text {th }}$ mile, Kapar Road, dalam Fail Setiausaha Kerajaan Negeri Selangor, Selangor Secretariat File 4604/1916.

36 Petition to open a toddy shop at Sabak Bernam, dalam Fail Setiausaha Kerajaan Negeri Selangor, Selangor Secretariat File 5857/1914.

37 Inspection Reports by Officers of the Labour Department On estates for the month of September 1925 - Report - Report Pemeriksaan Yang Diadakan Oleh Pegawai-pegawai Office Kuli-kuli Diatas Kebun-kebun 
Bagi Bulan September Tahun 1925 (Versi Melayu-Jawi), dalam Fail Setiausaha Kerajaan Negeri Kedah, Kedah Secretariat File 1015/1344.

Sale of drought beer opposite to Serendah Toddy Shop at Serendah, dalam Fail Pejabat Daerah Ulu Selangor, 1920-1934, PDUS 211/29. Surat daripada pengurus, ladang Serendah kepada Chairman, Licensing Board, Rasa, 8 Julai 1929 dan surat daripada District Officer, Ulu Selangor kepada District Office, Rasa, 29 Jun 1929. Annual Report of The Labour Department Coast District Selangor For The Year 1924, dalam Fail Setiausaha Kerajaan Negeri Selangor, Selangor Secretariat File 790/1925.

Ibid.

$41 \quad$ The Malay Mail, 18 Januari 1927.

42 'Seorang buruh Tamil dibunuh dalam pertempuran di ladang', Tamil Nesan, 6 April 1939, hlm. 9.

43 'Pertempuran, kesan minuman todi', Tamil Nesan, 20 April 1939, hlm. 3. Dalam tahun yang sama, Jabatan Buruh di Perak melakukan 245 lawatan termasuk 14 lawatan khas ke ladang-ladang kerana berlaku pergaduhan kalangan buruh-buruh India. Antara masalah yang membawa kepada pergaduhan ialah, gaji buruh tidak dibayar oleh majikan, dipecat kerja tanpa diberi notis, dilayan secara buruk oleh majikan dan juga masalah keluarga. Lihat, CO 438/5, Federated Malay States, Annual Report On The Social and Economic Progress of The People of Perak For The Year 1939, Kuala Lumpur: The F.M.S. Government Printing Office, 1940, hlm. 32-33.

Reopening of Estate Toddy Shops, dalam Fail Setiausaha Kerajaan Negeri Kedah, Kedah Secretariat File 228/46. Surat daripada Pegawai Perubatan Sentral Kedah kepada The State Surgeon, Alor Setar pada 30 Oktober 1946. Annual Report of The Agent of The Government of India In British Malaya For The Year 1928, Calcutta: Government of India, Central Publication Branch, 1929 \& Annual Report of The Agent of The Government of India In British Malaya For The Year 1929, Calcutta: Government of India, Central Publication Branch, 1930.

46 Nagendralingan Ratnavadivel, 'The History of Toddy and its impact on the socio-economic sphere of the Indian especially in Selangor with particular reference to the district of Kuala Langat 1900-1973', Latihan Ilmiah, B.A., Pusat Pengajian Ilmu Kemanusiaan, Universiti Sains Malaysia, Pulau Pinang, 1973/1974, hlm. 42.

47 Applies for a toddy shop licence in his estate for the year 1930, dalam Fail Pejabat Tanah Batu Pahat, 1914-1931, AABP 122/29. Surat daripada Manager Tanjong Labu Estate kepada The Assistant Adviser, Batu Pahat, 28 November 1929.

48 The Renewal of the Toddy shop Licence at Kan Kar Estate, dalam Fail Pejabat Tanah Batu Pahat, 1931-1946, AABP 250/33. Surat daripada ladang Kan Kar kepada The Chairman, The Licensing Board, Batu Pahat, 28 September 1933.

49 Applies for a toddy shop licence at Hua Hin Coconut Estate Batu Pahat, dalam Fail Pejabat Tanah Batu Pahat, 1914-1931, AABP 105/26. Surat 
daripada Tan Swee Hoe, Coconut \& Rubber Estate, Batu Pahat kepada The Chairman, Licensing Board, Batu Pahat, 8 Disember 1926.

50 Daripada kajian arkib yang dilakukan, jumlah tepat tentang penglibatan buruh India dalam pengambilan todi hanya dapat untuk negeri Johor.

51 Toddy Committee, dalam Fail Labour Department of Malaysia, 1945-1947, LDM 426/46, hlm. 2-3. 